\title{
Proceedings of the Third Freiburg Thrombosis Meeting
}

\section{How Blood Cells Contribute to Thrombosis}

\author{
Daniel Duerschmied ${ }^{1,2}$ \\ ${ }^{1}$ Department of Cardiology and Angiology I, Heart Center, University \\ of Freiburg, Freiburg, Germany \\ 2 Department of Internal Medicine III: Medical Intensive Care, Faculty \\ of Medicine, University of Freiburg, Freiburg, Germany \\ Hämostaseologie 2018;38:183-185.
}

Antithrombotic therapy is one of the cornerstones of cardiovascular medicine, and numerous patients with or at risk for myocardial infarction or stroke rely on it. Much has changed within recent years, and direct-acting oral anticoagulants are now the first choice for many patients requiring potent antithrombotic therapy. ${ }^{1,2}$ Combining antiplatelet drugs with anticoagulants remains a major challenge in the management of patients with several comorbidities (e.g. atrial fibrillation and acute coronary syndrome). ${ }^{3}$

During the 3rd Thrombosis Meeting in Freiburg in February 2018, several invited expert speakers and a lively audience took a close look at the state-of-the-art inhibition of platelets and coagulation factors-just 1 day after the exciting 62nd Annual Meeting of the Society of Thrombosis and Haemostasis Research (GTH) was successfully wrapped up in Vienna. Going beyond current concepts, recent discoveries in thrombus biology were discussed not only in Vienna, but now also in Freiburg, like the interplay between known thrombus components and the complement system ${ }^{4,5}$ and, of course, neutrophil extracellular traps (NETs). ${ }^{6}$ How external influences change haemostasis dramatically became evident when haemostasis testing in critically ill patients requiring extracorporeal membrane oxygenation (ECMO) was presented. ${ }^{7}$ Finally, looking at a collage of novel antithrombotic targets motivated the participants of this meeting to continue working toward further improvement of patient care.

With this theme issue in your hands, selected speakers of the Third Freiburg Thrombosis Meeting present the results of these discussions in concise review articles. As the organizer of the Freiburg Thrombosis Meeting, I hope very much that our readers will enjoy this overview of thrombus formation and inhibition. With this theme issue, I also want to thank all speakers, who came to Freiburg on that day: Christoph Bode,

Address for correspondence Prof. Dr. Daniel Duerschmied, MD, Department of Cardiology and Angiology I, Heart Center, University of Freiburg, Hugstetter Str. 55, 79106 Freiburg, Germany (e-mail: daniel.duerschmied@ universitaets-herzzentrum.de).

former president of the GTH and chairman of our department (and my mentor), moderated the meeting. Harald Langer from Tübingen presented very novel data suggesting an important role of complement receptors in platelet biology. ${ }^{5}$ In this issue, he summarizes this novel and previous knowledge. ${ }^{8}$ Tom Eirik Mollnes from Oslo as second speaker added recent data linking the complement and coagulation systems, when he showed how Staphylococcus aureus induces coagulation by complement activation. ${ }^{4}$ Both are intriguing novel aspects of immunothrombosis. ${ }^{9}$

Rüdiger Scharf, Editor-in-Chief of Hämostaseologie Progress in Haemostasis, past GTH congress president and renowned expert of platelet biology and pathology, invited the audience to take a fascinating look at complex platelet mechanisms. In this issue, he summarizes, weighs, reviews and critically discusses platelet signalling in a two-part overview. ${ }^{10,11}$ I find his ideas and illustrations very stimulating and highly valuable.

Tobias Fuchs from Hamburg discovered NETs in thrombi together with Denisa Wagner from Boston in 2009. ${ }^{12} \mathrm{He}$ related to his initial experiments and also showed very exciting new findings, suggesting that NETs may indeed become an interesting antithrombotic target. ${ }^{6}$ Christoph Reinhardt from Mainz then disclosed how gut microbiota influence thrombus initiation and formation-a novel aspect that some clinicians had been anticipating for a long time. ${ }^{13}$ His findings are also presented in this issue. ${ }^{14}$

Carlos Silvestre-Roig from Munich examined and illustrated the contribution of neutrophils to atherosclerosis and atherothrombosis. ${ }^{15}$ Jolanta Siller-Matula from Vienna is an expert in platelet function testing and made an important point, when she advocated for personalized medicine with the state-of-the art phenotyping of patients treated with antiplatelet drugs. ${ }^{16}$ Barbara Zieger from Freiburg thrilled

(c) 2018 Georg Thieme Verlag KG Stuttgart · New York
DOI https://doi.org/ $10.1055 / \mathrm{s}-0038-1675150$. ISSN 0720-9355. 
us with her troubling description of the altered haemostatic system with acquired von Willebrand syndrome in patients under ECMO support. ${ }^{7}$

Meinrad Gawaz from Tübingen provided pragmatic suggestions for optimal antiplatelet therapy-which he shares in this issue. ${ }^{17}$ Ingo Hilgendorf from Freiburg nicely compiled the most promising novel antithrombotic targets that he delineates and discusses in this issue. ${ }^{18}$ Dietmar Trenk from Bad Krozingen showed surprising features-and clinical consequences-of reticulated platelets, a very reactive, RNA-rich platelet subpopulation. ${ }^{19}$ He will further discuss this aspect in an upcoming issue of Hämostaseologie. Martin Moser from Freiburg finally presented the novel concept of adding low-dose rivaroxaban to long-term antiplatelet therapy in high-risk patients with vascular disease. ${ }^{20}$ This dual-antithrombotic concept is reviewed by Samer Al Said et al in this issue. ${ }^{21}$ Gerd Heusch from Essen was a highly appreciated discussant, enthusiastically chairing and moderating interesting sessions.

As organizer of this year's Freiburg Thrombosis Meeting and guest editor of this theme issue of Hämostaseologie Progress in Haemostasis, I am inviting you to share our enthusiasm for improving antithrombotic therapy. Please deal with the review articles of this edition in detail, discuss them with your co-workers, relate to them whenever you wish and get back to us with any questions or comments you may have.

\section{References}

1 Kirchhof P, Benussi S, Kotecha D, et al; ESC Scientific Document Group. 2016 ESC Guidelines for the management of atrial fibrillation developed in collaboration with EACTS. Eur Heart J 2016;37 (38):2893-2962

2 Konstantinides SV, Torbicki A, Agnelli G, et al; Task Force for the Diagnosis and Management of Acute Pulmonary Embolism of the European Society of Cardiology (ESC). 2014 ESC guidelines on the diagnosis and management of acute pulmonary embolism. Eur Heart J 2014;35(43):3033-3069, 3069a-3069k

3 Duerschmied D, Brachmann J, Darius H, et al. Antithrombotic therapy in patients with non-valvular atrial fibrillation undergoing percutaneous coronary intervention: should we change our practice after the PIONEER AF-PCI and RE-DUAL PCI trials? Clin Res Cardiol 2018;107(07):533-538
4 Skjeflo EW, Christiansen D, Fure H, et al. Staphylococcus aureusinduced complement activation promotes tissue factor-mediated coagulation. J Thromb Haemost 2018;16(05):905-918

5 Sauter RJ, Sauter M, Reis ES, et al. A functional relevance of the anaphylatoxin receptor C3aR for platelet function and arterial thrombus formation marks an intersection point between innate immunity and thrombosis. Circulation 2018:CIRCULATIONAHA.118.034600

6 Jiménez-Alcázar M, Rangaswamy C, Panda R, et al. Host DNases prevent vascular occlusion by neutrophil extracellular traps. Science 2017;358(6367):1202-1206

7 Kalbhenn J, Schlagenhauf A, Rosenfelder S, Schmutz A, Zieger B. Acquired von Willebrand syndrome and impaired platelet function during venovenous extracorporeal membrane oxygenation: rapid onset and fast recovery.J Heart Lung Transplant 2018;37(08):985-991

8 Eisinger F, Langer HF. The mutual relation of platelet activation and innate immunity. Hamostaseologie 2018;38(04):186-202

9 Engelmann B, Massberg S. Thrombosis as an intravascular effector of innate immunity. Nat Rev Immunol 2013;13(01):34-45

10 Scharf R. Platelet signaling in primary hemostasis and arterial thrombus formation: part 1. Hamostaseologie 2018;38(04):203-210

11 Scharf R. Platelet signaling in primary hemostasis and arterial thrombus formation: part 2. Hamostaseologie 2018;38(04):211-222

12 Fuchs TA, Brill A, Duerschmied D, et al. Extracellular DNA traps promote thrombosis. Proc Natl Acad Sci U S A 2010;107(36): 15880-15885

13 Jäckel S, Kiouptsi K, Lillich M, et al. Gut microbiota regulate hepatic von Willebrand factor synthesis and arterial thrombus formation via Toll-like receptor-2. Blood 2017;130(04):542-553

14 Reinhardt $C$. The microbiota as an environmental risk factor for thrombosis). Hamostaseologie 2018;38(04):223-228

15 Winter C, Silvestre-Roig C, Ortega-Gomez A, et al. Chrono-pharmacological targeting of the CCL2-CCR2 axis ameliorates atherosclerosis. Cell Metab 2018;28(01):175-182.e5

16 Winter MP, Grove EL, De Caterina R, et al. Advocating cardiovascular precision medicine with P2Y12 receptor inhibitors. Eur Heart J Cardiovasc Pharmacother 2017;3(04):221-234

17 Rath D, Gawaz M. Antiplatelet treatment for catheter-based interventions in high-risk patients: current guidelines and expert opinion). Hamostaseologie 2018;38(04):229-235

18 Bäuml M, Hilgendorf I. Future antithrombotic therapies in cardiology. Hamostaseologie 2018;38(04):236-239

19 Stratz C, Nührenberg T, Valina CM, et al. Impact of reticulated platelets on the antiplatelet effect of the intravenous P2Y12-receptor inhibitor cangrelor. Thromb Haemost 2018;118(02):362-368

20 Eikelboom JW, Connolly SJ, Bosch J, et al; COMPASS Investigators. Rivaroxaban with or without aspirin in stable cardiovascular disease. N Engl J Med 2017;377(14):1319-1330

21 Al Said S, Bode C, Duerschmied D. Anticoagulation in atherosclerotic disease. Hamostaseologie 2018;38(04):240-246 